Chirurgia (2017) 112: 77-81

No. 1, January - February

Copyright@ Celsius

http://dx.doi.org/10.21614/chirurgia.112.1.77

\title{
Laparoscopic Partial Adrenalectomy
}

\author{
Adrian Miron ${ }^{1,2}$, Cosmin Giulea ${ }^{1,2}$, Mihai Nădrăgea', Octavian Enciu' ${ }^{1,2}$ \\ 'Department of Surgery, Elias University Emergency Hospital, Bucharest, Romania \\ ${ }^{2}$ Carol Davila University of Medicine and Pharmacy, Department 10 - Surgery, Bucharest, Romania
}

Corresponding author:

Professor Adrian Miron,

Elias University Emergency Hospital

Blvd. Mărăști, no. 17, district 1

Bucharest, Romania

E-mail: dramiron@yahoo.com

\section{Rezumat}

Suprarenalectomia parțial laparoscopică

Suprarenalectomia laparoscopicã a devenit gold standard pentru afecțiunile suprarenalei, de la incidentalom pânã la cancer. Suprarenalectomia parțialã este greu de acceptat din cauza dificultãților tehnice şi a riscurilor hemoragie, nefiind stabilit un consens. Pe de altã parte, în cazuri selecționate de tumori benigne, suprarenalectomia poate fi excesivã, rezecțiile parțiale fiind perfect justificate cu risc hemoragic scãzut. Pentru tumori secretante de dimensiuni sub $3 \mathrm{~cm}$, cu localizare anterioarã sau lateralã, suprarenalectomia parțialã poate fi indicatã. Reperele principale sunt reprezentate de identificarea adenomului, conservarea țesutului glandular restant împreunã cu sursele vasculare şi disecția precisã cu menținerea spațiului de clivaj între adenom şi restul parenchimului. Suprarenalectomia parțial laparoscopicã este fezabilã şi eficientã pentru tratamentul tumorilor de mici dimensiuni mai ales în localizãrile bilaterale. Aceste avantaje sunt contrabalansate de o tehnicã chirurgicalã mai dificilã.

Cuvinte cheie: chirurgie laparoscopicã, suprarenalectomie, rezecție suprarenalianã parțialã

\section{Abstract}

Laparoscopic adrenalectomy became the gold standard for adrenal disease, from incidentaloma to cancer. Partial adrenalectomy is difficult to accept due to its technical difficulties as well as hemorrhagic risk and a consensus has not been reached. On the other hand, in selected cases of benign adrenal tumors, adrenalectomy may be futile, partial resections being perfectly justified and with lower hemorrhagic risks. For functioning tumors smaller than $3 \mathrm{~cm}$ with an anterior or lateral location, partial adrenalectomy may be indicated. The key points reside in adenoma identification, preservation of the remaining glandular parenchyma and its blood supply with dissection in the space between the adenoma and the normal parenchyma. Laparoscopic partial adrenalectomy is feasible and effective for the treatment of benign tumors. 
Although partial resections have clear-cut advantages over conventional adrenalectomy especially for bilateral tumors, it remains a difficult intervention.

Key words: laparoscopic surgery, adrenalectomy, partial adrenal resection

\section{Introduction}

Laparoscopic adrenalectomy is the gold standard for the treatment of patients with adrenal tumors without local or regional extension (1). With a number of laparoscopic approaches in use, most commonlytransperitoneal, the resection is safe and effective in experienced hands with thorough follow up by the endocrinologist $(1,2)$.

While most laparoscopic adrenalectomies involve complete resection of the adrenal gland, partial or limited resections have been scarcely reported with no consensus being reached regarding partial adrenalectomy. The fact that a second normal adrenal gland exists does not justify in all cases the complete removal of the diseased gland. Furthermore, partial adrenalectomy may be the choice for bilateral lesions $(3,4)$.

Partial adrenalectomy has been proven feasible but the indications and techniques in published reports are varied. Most authors agree that small functioning tumors with less than $3 \mathrm{~cm}$ in diameter, located laterally or anteriorly in order to preserve the adrenal vein represent an indication for partial resection. (5) A concentric location in the gland or a diameter of more than $3 \mathrm{~cm}$ represent an exclusion criteria for most authors. The indicated safety margins are between $2-3$ and $5 \mathrm{~mm}$ but in our opinion resection of an adenoma without damaging its capsule is safe.

All adrenal tumors require preoperative CT scans to determine the exact location and size (Figs. 1 and 2). Some authors have also suggested intraoperative laparoscopic ultrasound for confirmation $(5,6)$.

\section{Technique}

We usually perform this operation through a transperitoneal approach with standard laparoscopic adrenalectomy trocar placement.

The right laparoscopic partial adrenalectomy starts by mobilizing the right lobe of the liver. Good exposure requires retraction of the liver from the operative field, allowing easier access to the vessels. The gallbladder, which is situated outside of the operating field, is left untouched. With the liver mobilized, we come into the retroperitoneal space by making an incision in the subhepatic peritoneum with either a coagulating hook or scissors. The right kidney is revealed and the right adrenal gland comes into view. The vena cava is dissected first because it is easily identified and leads directly to the right adrenal gland (Fig. 3). Only the vena cava and the right renal vein are dissected respectively, to the left and caudally, to determine

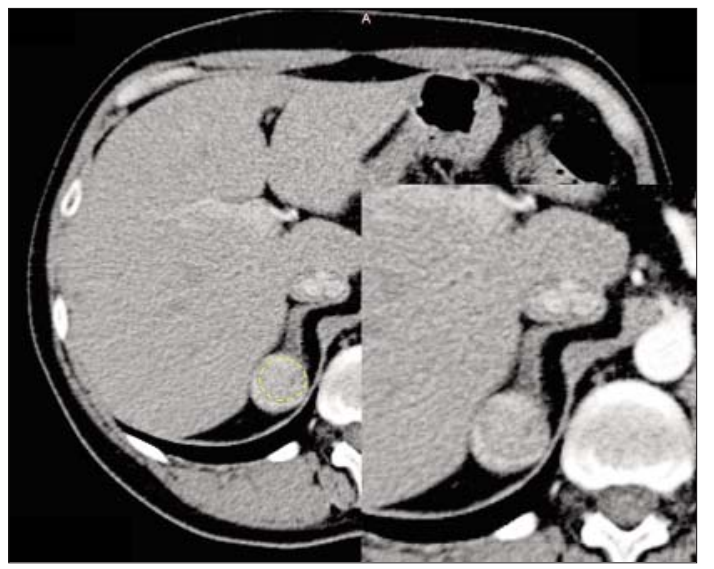

Figure 1. Right adrenal adenoma - Cushing Syndrome

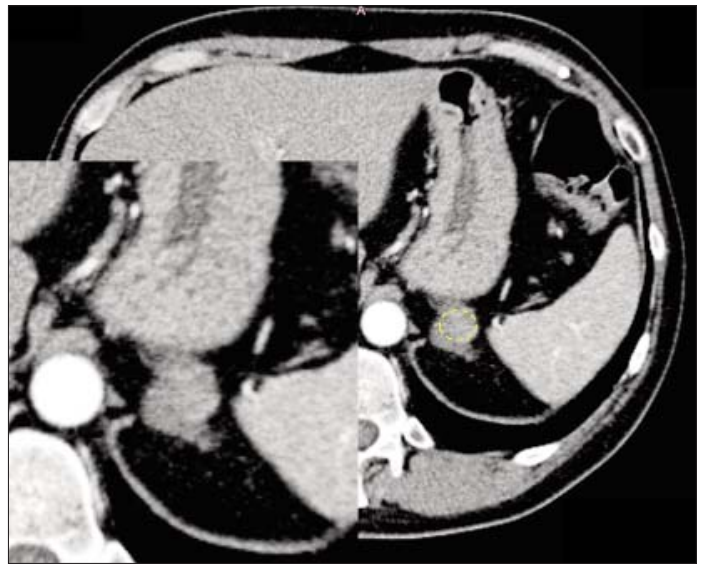

Figure 2. Left adrenal incidentaloma 


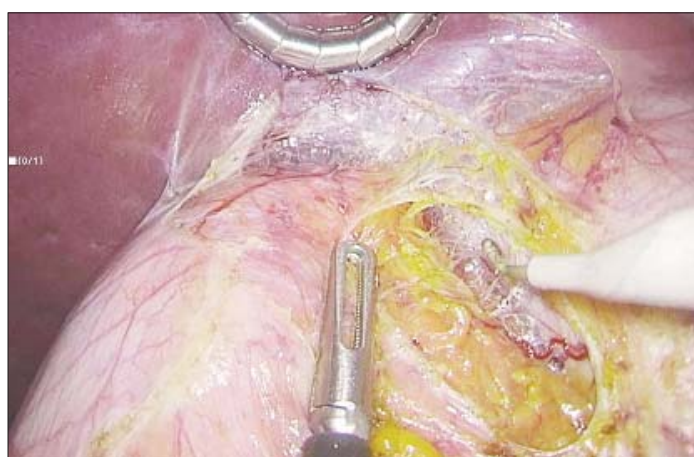

Figure 3. Dissection of the right borded of the inferior vena cava

the limits of the operating field. It is important to expose the margins of the whole gland and the tumor completely before beginning the partial resection.

The dissection begins on the left aspect of the gland in order to expose the vena cava. The vena cava constitutes the main anatomical landmark in this strategy and it is very carefully dissected using the dissector and the hook. We dissect the vena cava just below the liver and we have to be extremely careful to visualize a possible short hepatic vein in this area. Here we consider the top edge of the adrenal gland. We continue carefully the dissection with a hook or a scissors on the lateral side of the vena cava. The dissection continues cephalad on the right aspect of the vena cava since it is the anatomical landmark used to identify the main adrenal vein. The main adrenal vein always seems to be situated lower than it actually is. For a better liver retraction we switch the liver retractor and the adrenal gland can be seen quite clearly now. Blunt dissection is continued and the adrenal vein is identified and carefully dissected. The vein will be preserved, if possible (7).

We begin to dissect the adrenal gland, on the lateral side, separating it from the kidney. We continue the dissection to the posterior aspect of the gland. To preserve the blood supply of the remnant adrenal gland, mobilization of the tumor within benign margins should be started at the side of the tumor. Furthermore, the unaffected portion of the gland should not be dissected. We try to hold the tumor as little as possible. Some posterior attachments still remain. Inferior attachments are taken with a coagulating hook, if possible, or, instead of this, with a LigaSure ${ }^{\mathrm{TM}}$ or Thunderbeat ${ }^{\mathrm{TM}}$. Now we begin to divide between the tumor and the normal tissue of the gland. We transect below and medially of the adenoma, through the normal gland. The tumor resection itself is carried out with a surgical device for coagulation and sealing. The resection line is performed at a distance of 2 or $3 \mathrm{~mm}$ from the tumor (Figs. 4 and 5). This kind of sectioning avoids arterial or venous bleeding. The pressure of the pneumoperitoneum largely prevents parenchymal bleeding. We continue the sectioning, and as we come across the gland, the hemostasis is excellent, and as we retract the adrenal mass superiorly we see that there are a few attachments left. We cut these attachments and the tumor is completely divided now. The resected tumor is put in an endobag and parked in the abdomen (Fig. 6). After a lavage of the remnant cavity (Fig. 7), Surgicell ${ }^{\mathrm{TM}}$ is applied on the sectioned tissue and the operation is completed. To avoid venous bleeding after releasing the pneumoperitoneum, some authors suggest sealing the remnant parenchyma with 1 $\mathrm{mL}$ of fibrin glue (3).

The tumor was then retrieved from the abdomen within the endobag by slightly widening one of the trocar incisions.

On the left side, for the left laparoscopic partial adrenalectomy, the main steps are similarly carried out (Figs. 8-11).

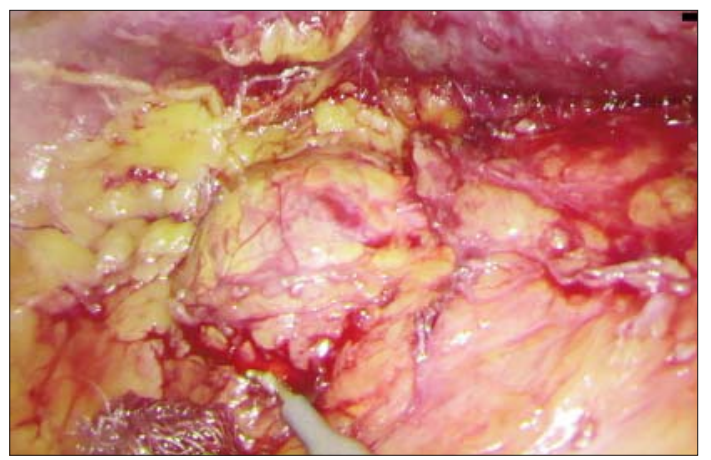

Figure 4. Dissection of the right sided adenoma

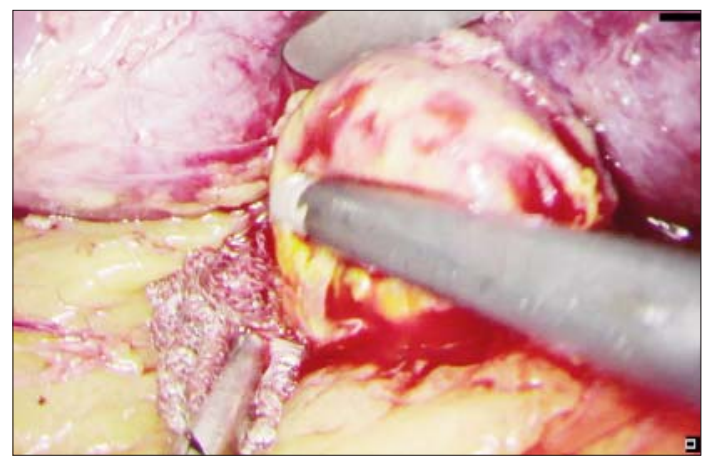

Figure 5. Complete mobilization of the adenoma 


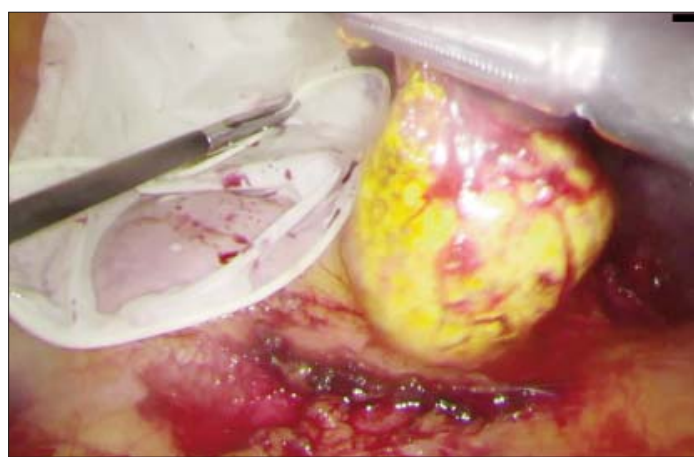

Figure 6. Resection of the adenoma

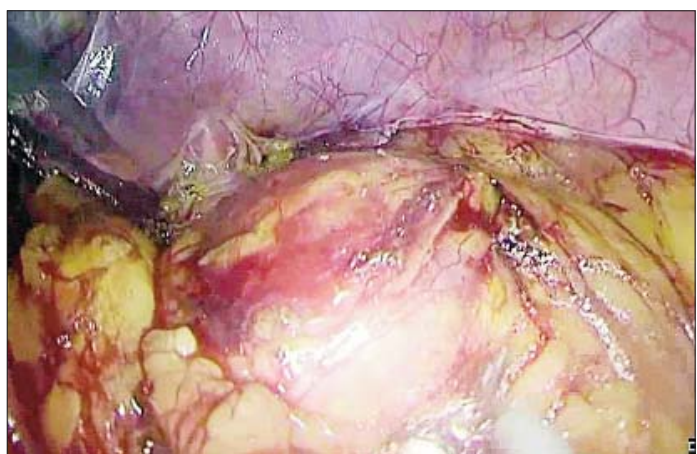

Figure 8. Left partial adrenalectomy - identification of the incidentaloma with clear cut margins

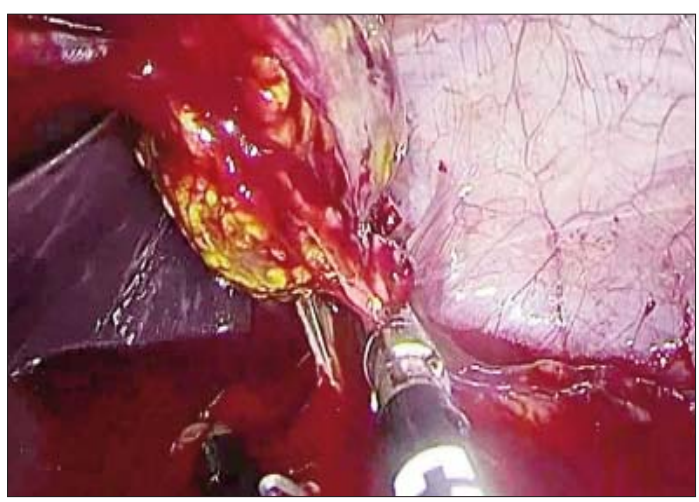

Figure 10. Selective final vessel sealing

\section{Discussion}

Laparoscopic surgery for adrenal lesions has been proven superior to open surgery and since most adrenal tumors are benign, partial resections should be taken into consideration (8).

The fact that the adrenal glands are paired organs and steroid replacement is not needed after unilateral adrenalectomy may be the reason for the few reports of partial resections. But in the case the

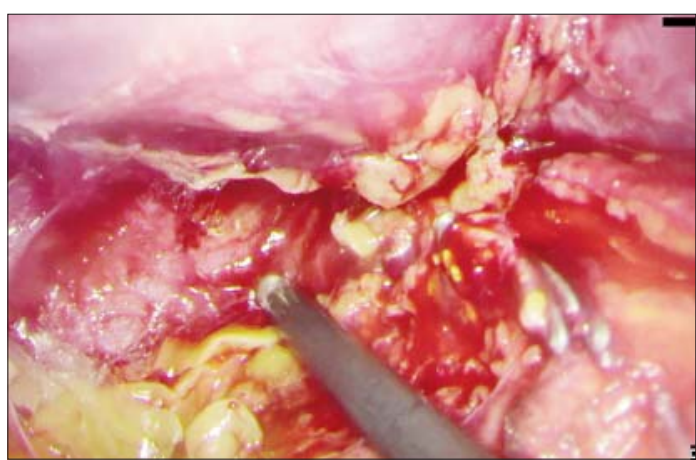

Figure 7. Remnant cavity with preservation of normal parenachyma

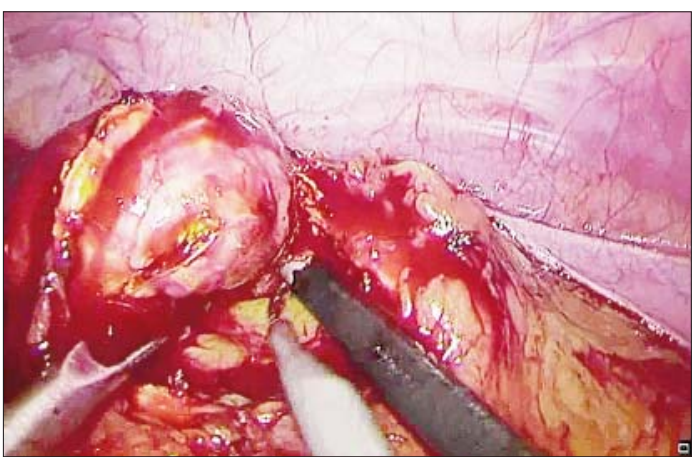

Figure 9. Dissection in progress of the left sided incidentaloma

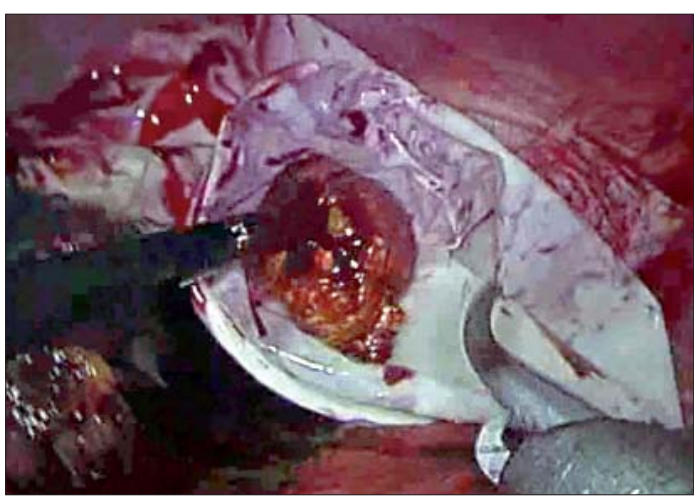

Figure 11. Secured specimen retrieval

second adrenal is lost, steroid replacement is a certainty with all its consequences.

Altogether, partial adrenal resection is a more difficult, not yet standardized procedure. The risk of parenchymal bleeding is higher than in the standardized complete adrenalectomy even though advanced sealing devices exist. The use of vascular staples for transecting such a small organ in our opinion are to be avoided since more normal parenchyma will be sacrificed. Laparoscopy offers 
more precision when it comes to opening the cleavage plane between the tumor and the normal parenchymal that will be spared.

The main indications for partial adrenalectomy are small functioning tumors, aldosterone producing adenomas, other benign tumors such as myelolipoma and in some cases of pheocromocy ${ }^{-}$ toma $(9,10)$. The lesions should be thoroughly investigated preoperatively in order to be certain partial resection will be performed in patients with benign lesions.

\section{Conclusion}

Laparoscopic partial adrenalectomy for small benign adrenal tumors is feasible and safe. The main advantage of this technique is preserving normal secreting parenchyma which makes it an ideal solution for bilateral tumors.

\section{References}

1. Gagner M, Pomp A, Heniford BT, Pharand D, Lacroix A. Laparoscopic adrenalectomy: lessons learned from 100 consecutive procedures.
Ann Surg. 1997;226(3):238-46; discussion 246-7.

2. Duh QY, Siperstein AE, Clark OH, Schecter WP, Horn JK, Harrison MR, et al. Laparoscopic adrenalectomy: comparison of the lateral and posterior approaches. Arch Surg. 1996;131(8):870-5; discussion 875-6.

3. Jeschke K, Janetschek G, Peschel R, Schellander L, Bartsch G, Henning K. Laparoscopic partial adrenalectomy in patients with aldosterone-producing adenomas: indications, technique, and results. Urology. 2003;61(1):69-72.

4. Janetschek G, Lhotta K, Gasser R, Finkenstedt G, Jaschke W, Bartsch G. Adrenal-sparing laparoscopic surgery for aldosterone-producing adenoma. J Endourol. 1997;11(2):145-8.

5. Imai T, Tanaka Y, Kikumori T, Ohiwa M, Matsuura N, Mase T, et al. Laparoscopic partial adrenalectomy. Surg Endosc. 1999;13(4):343-5.

6. Zielke A, Rothmund M. Adrenal imaging procedures. In: Clark $\mathrm{OH}$, Duh QY (eds). Textbook of endocrine surgery. Philadelphia, London, Toronto, Montreal, Sydney, Tokyo: WB Saunders; 1997. p 466-474.

7. Roukounakis N, Dimas S, Kafetzis I, Bethanis S, Gatsulis N, Kostas $\mathrm{H}$, et al. Is preservation of the adrenal vein mandatory in laparoscopic adrenal-sparing surgery?. JSLS. 2007;11(2):215-8.

8. Vaughan ED Jr, and Blumenfeld JD. The adrenals. In Walsh PC, Retik AB, Vaughan ED Jr, et al (Eds). Campbell's Urology, 7th ed. Philadelphia: WB Saunders; 1998. p 2915-2927.

9. Walther MM, Herring J, Choyke PL, Linehan WM. Laparoscopic partial adrenalectomy in patients with hereditary forms of pheochromocytoma. J Urol. 2000;164(1):14-7.

10. Neumann HP, Reincke M, Bender BU, Elsner R, Janetschek G. Preserved adrenocortical function after laparoscopic bilateral adrenal sparing surgery for hereditary pheochromocytoma. J Clin Endocrinol Metab. 1999;84(8):2608-10. 